\title{
Child Rearing in the Family: Social Perspective in Latvia
}

\author{
Nora Jansone-Ratinika, Dace Medne and Ilze Dinka
}

\begin{abstract}
Transformations in the socio-political situation of Latvia after regaining independence in 1991 initiated a search for and presentation of a new emphasis on family pedagogy, which determined the dominant discourses in the topic of child rearing. The situation reveals a problem of research and substantiates our aim: to identify and analyse how the change in the discourse of child rearing reflects the dynamics of pedagogical thought in Latvia from 1990 to 2004. Our study was quantitative, applying content analysis and discourse analysis methods that allow analytical and descriptive comparisons of the narratives in My Little One and Yearbook with concepts in pedagogical literature and other sources. Ideological attitudes during the periods of post-independence and Europeanisation reveal dual tendencies: society is partially inclined to renew the patriarchal order of the interwar period, but advancement of democracy and emancipation determines reformation of the traditional order. Even though family is assigned an important role at the state level, proposed support and initiatives do not form a holistic framework of assuring resources. An obstacle for unified advancement is seen in polarisation - categorical denial of the ideological settings and practices of the Soviet period or glorification of the pedagogical ideas of the interwar period and uncritical euphoric acceptance of international tendencies.
\end{abstract}

Keywords: child rearing, social perspective in Latvia, media, pedagogical literature discourse

United Nations Universal Declaration of Human Rights has declared that childhood is entitled to special care and assistance, convinced that family, as the core group of society and the natural environment for the growth and well-being of all its members and particularly children, should be afforded the necessary protection and assistance so that it can fully assume its responsibilities within the community, recognizing that the child, for the full and harmonious development of his or her personality, should grow up in a family environment, in an atmosphere of happiness, love and understanding, considering that the child should be fully prepared to live an individual life in society, and brought up in the spirit of the ideals proclaimed in the Charter of the United Nations, and in particular in the spirit of peace, dignity, tolerance, freedom, equality and solidarity. ${ }^{1}$

1 United Nations, 'Convention on the Rights of the Child. Signed 20 November 1989,' Latvijas Vēstnesis [Latvia's Herald], 28 November 2014. Available: https://www.vestnesis.lv/ op/2014/237.16 (accessed 5 October 2019). 
The correct path to a genuinely happy society is by helping children and the families in which they are raised. And so little is required to come closer to this goal - a small amount of civic courage, a heartfelt approach, and wisdom in everyday work and life. ${ }^{2}$

\section{Introduction}

Transformation in the socio-political situation of Latvia after regaining independence in 1991 initiated changes in society and raised the need for transformation of perceptions and processes related to society in general, as well as for social groups - families and individuals, children, fathers, and mothers. This situation initiated a search for a new focus and introduction of family pedagogy, which determined the discourse in child rearing. From 1990 to 2004, child rearing theories and practice were intertwined with the search for new reference points in time and space. Social processes related to economical and political instability in the state directly impacted the well-being of the family and the individual, both in daily practical issues and in the ideological dimension. This caused changes in perceptions and attitudes of people and initiated the need for radical social innovations.

Social rearrangements in Latvian society after regaining independence have not been fully researched, so the objective of this study is to identify and analyse how the transformation of the discourse of child rearing reflected the dynamics of pedagogical thought in Latvia from 1990 to 2004. How did changes in the discourse of child rearing take place?

Various perceptions and applications of child rearing in literature are outlined in this study: explanations of child rearing ideas in social practice ${ }^{3}$ (changes in aims, approaches, and their relation and interactions in the frame of the family model) in the family from the dimension of the media narrative (thinking, viewpoints) and instruments (practices, actions). In turn, pedagogic thought is perceived as a conceptualised and scientifically justified totality of theory and practice typical for the society of Latvia during this period.

\section{Source description and research methodology}

Sources published from 1990 to 2004 were selected: the magazine Mans Mazais ${ }^{4}$ [My Little One] (MLO), the yearbook Mājai un gimenei ${ }^{5}$ [For Home and Family] (Yearbook), pedagogical literature, academic studies, and documents were analysed to reconstruct family child rearing in the social perspective.

2 A. Jākobsone, 'Ievads' [Introduction], in Bèrni un gimenes Latvijā 1994 [Children and families in Latvia], Rīga, AS Preses nams, 1995, p. 9.

3 T. A. Van Dijk, Discourse Studies: A Multidisciplinary Introduction. Discourse as Social Interaction, UK, Sage Publications, 2011, p. 432.

4 Analysis included 3642 articles published in the magazine My Little One from 1994 to 2004.

5 Analysis included 30 articles published in the Yearbook from 1990 to 1996. 
Pedagogical literature, expressing and analysing current trends, impacts the viewpoints of parents, educators, and society in general in regard to pedagogical attitudes, thus altering also the practice of child rearing. As several scholars note, mass media helps people to construct their cultural experiences, ${ }^{6}$ influencing everyday behavior and forming and replicating ideas, opinions, judgments, standards, and values, thus determining public opinion both philosophically, didactically, and ethically. ${ }^{7}$ MLO and Yearbook can be considered important agents in the discourse of child rearing, comparable in regards to the source type and target audience.

From 1990 to 1996, Yearbook had four compilers, who were leading Latvian journalists and public figures at the time. The price of the Yearbook made it accessible to families with average income. The Yearbook described its target audience - Latvian parents and families - as the community of readers of yearbooks and calendars to whom this Yearbook served as a guide not only for advice on farming, cattle-breeding, household management, and maintaining a healthy lifestyle, but also ethics for the family and upbringing of children. ${ }^{8}$ The compilers expressed the situation of society in the second yearbook with the words of Hamlet, "when the time is out of joint", and characterised the publication as a signpost between the cultural heritage of the Latvian mentality and new trends in educating the population. ${ }^{9}$

From MLO, which is still published, 105 issues were analysed with 3642 articles. Initially, the magazine was published four to six times annualy, but since 1997 it has been published monthly. MLO can be considered a stable, illustrated popular science publication and a significant voice in the discourse of family pedagogy. The publication has had several journalists as editor-inchief. MLO cannot be classified as a professional pedagogical periodical; it positioned itself as a parental lifestyle magazine, similar to men's and women's lifestyle magazines that gained popularity at the end of $1990 \mathrm{~s} .{ }^{10}$ The mission of MLO, to "discover the world of the child, beginning with practical issues and concluding with psychological conversations", was achieved by passing

\footnotetext{
${ }^{6}$ Z. Rubene, 'Homo Medialis kā izpētes fenomens pedagog̣iskajā antropolog̣ijā' [Homo Medialis as a research phenomenon in pedagogical anthropology], in T. Koķe, B. Kalı (eds.), LU Raksti. Pedagoǵija un skolotāju izglìtība [Articles of the University of Latvia. Pedagogy and teacher education], vol. 781, Rīga, LU Akadēmiskais apgāds, 2012, pp. 10-17.

${ }^{7}$ I. Ķestere, Z. Āḳite, 'Pedagog̣ijas mācību grāmata kā medijs jauna cilvēka audzināšanai: Latvijas pieredze 19. un 20. gadsimtä' [Pedagogy textbook as a medium for nurturing a young person: the experience of Latvia in the $19^{\text {th }}$ and $20^{\text {th }}$ century], in T. Koķe, B. Kalıke (eds.), LU Raksti. Pedagogija un skolotāju izglitība [Articles of the University of Latvia. Pedagogy and teacher education], vol. 781, Rīga, LU Akadēmiskais apgāds, 2012, pp. 200-210.

${ }^{8}$ O. Zanders, 'Cel̦avārdi, gaitu sākot' [Good luck wishes on a new journey], in Gadagrāmata'90 'Mājai un gimenei' [Yearbook'90 'For home and family'], Rīga, Avots, 1989, pp. 28-31.

${ }^{9}$ A. Galandere, 'Cienījamo lasîtāj!' [Dear reader!], in Gadagrāmata'91 'Mājai un ǵimenei' [Yearbook'91 'For home and family'], Rìga, Avots, 1990, pp. 33-34.

${ }^{10} \mathrm{~S}$. Veinberga, Mediju misija. Preses attīstības tendences Latvijā pēc valsts neatkarïbas atjaunošanas (1990-2010) [Media mission: Press development trends in Latvia after the restoration of independence (1990-2010)], Rīga, Zvaigzne ABC, 2010, p. 160.
} 
the message on to "modern parents", their potential target audience. The key idea of the magazine was to "find the way to successfully combine individual desires and responsibilities of motherhood", as well as the call for action typical for the 1990s - define "the role of the loyal father in the family". "The conceptual framework of the magazine described every moment in the life of a child, who was an eternal source of joy and care to his/her parents at every moment of life: the quality of the child's life was the aim of the entire discourse. ${ }^{12}$ The content of the information initially included in the magazine was about children from 0 to 12 years, but after 2000 it was reduced to 7 years. The magazine included articles about the development, health, and child rearing, as well as relations in the family and society, depicting life with children from the moment of conception to the start of school. ${ }^{13}$

Study was quantitative, applying content and discourse analysis methods that allowed to analytically and descriptively compare MLO and Yearbook narratives with concepts found in pedagogical literature and other sources.

To analyse linguistic content of MLO and Yearbook narratives, key factors raising primary associations were selected - family, child, father, and mother representing the core of the family. Secondary selections identified adjectives of the actors and their activities with identical and close substantial meaning forms of names in different cases, singular or plural (for example, baby, mother, newborn, grandparents, daughter, child rearing, family etc.), characterising key roles and functions fulfilled by the main actors.

The first linguistic content analysis of the titles of MLO articles was performed using the quantitative data processing program QSR NVivo 11, but Yearbook content, pedagogical literature, and other sources were analysed manually. A computer program was selected based on several functional benefits: (1) automising initial starting data mass and manually applying it to the ideological essence during later stages of analysis. This allowed convenient summarisation and systematisaton of qualitative data and performance of simple content analysis, identifying most frequently encountered names, contexts, and meanings of their use; (2) provided the possibility to filter large volumes of data in different correlations and contexts automatically, therefore methodologically precisely in a brief period of time, thus significantly accelerating analysis and making it more objective; and (3) software consecutively stores the historical commands allowing the researcher to manage the course of coding and analysis of the content in a meaningful way. ${ }^{14}$

Data was processed and analysed on several levels. Firstly, content units of press publication titles were imported in the NVivo file where they were

11 'Redaktora sleja' [Editor's column], Mans Mazais [My little one], no. 1, 1994, pp. 1-2.

${ }^{12}$ R. Vasile, 'Kad jūs vai es (vai mēs) sakām - mans mazais' [When you or I (or we) say - my little one], Mans Mazais [My little one], no. 1, 1994, p. 2.

13 'Positioning of the magazine MLO in the Latvian press publications catalogue.' Available: https://abone.pasts.lv/lv/latvijas_preses_izdevumi/zurnali/2015/ (accessed 17 September 2017).

14 A. Bryman, Social Research Methods, UK, Oxford University Press, 2016, pp. 604-617; P. Bazeley, K. Jackson, Qualitative Data Analysis with NVivo, London, SAGE Publications, 2013. 
technically edited and openly coded in a consecutive manner; initially a 3000word frequency was set and then weighted to the ratio of frequency: 184 words were identified and selected and from them, 50 basic key words (codes) that characterise the basic factors of the nuclear family in terms of content were determined. Secondly, we performed hierarchic coding-grouping to determine thematically related key words and groups, frequency of their use, and mutual contextual meanings that disclosed the essence of the focus 'child rearing in the family' in terms of content. The final level was the basis of the structure of codes developed in content analysis and in-depth study of the interpretation of content and mutual coherence in the publications to test the validity of the contextual meaning of titles and to identify trends.

\section{Family and child in the crossfire of the socially political situation}

Drastic changes in politics, economics, culture, and education after Latvia regained independence ${ }^{15}$ initiated a quest for structure on the levels of the individual, family, community, and state. A situation without established and stable key values, a clearly-defined future direction, or determined and imposed priorities of action can be, on the one hand, a threat because the processes that take place are diffuse. But a different perspective might accentuate the constant, dynamic development of society, institutions, family, and the individual. A politically-charged new social situation created two directions: erosion of past approaches and anti-nostalgia concepts infiltrated society about the Soviet past $^{16}$ and new future-related quests in various areas. The times did not allow the ability to come to terms with what was achieved and created before but anticipated intense revision of the past and present, resulting in creativity in many areas. The quest of Latvian society is also depicted in the sources of this study. Questions were asked indirectly and directly - where are we going, what can we value now, to whom should we listen, in which direction should we look, is everything from the past worthless and everything from future desirable?

Family life cannot be separated from the social space, changes in the era, and society-initiated changes in socio-cultural components. The harsh survival mode many families were put into made it clear that independence and prosperity were not inseparable notions or even synonyms. The overall

${ }^{15}$ I. Kestere, A. Grāvite, 'Daži Latvijas augstākās izglītības ekspansijas aspekti' [Several aspects of higher education expansion], in T. Koķe, A. Krūze, D. Markus (eds.), Apvienotais pasaules latviešu zinātnieku 3. kongress un letonikas 4. kongress. Zinātnisko rakstu kräjums CD formātā. Izglitīibas izaugsmei: pagātne, tagadne un nākotne [Third world congress of Latvian scientists and fourth congress of Latvian studies. Scientific article collection in a CD format. For educational growth: Past, present and future], Riga, 2011, pp. 1-9.

${ }^{16}$ J. Ekman, J. Linde, 'Communist Nostalgia and the Consolidation of Democracy in Central and Eastern Europe,' Journal of Communist Studies and Transition Politics, vol. 21, no. 3, 2005, pp. 359361; M. Kaprāns, 'Padomju laika sociālās reprezentācijas latviešu pēcpadomju biogrāfiskajā diskursäa' [Social representations of Soviet era in post-Soviet Latvian biographical discourse], PhD diss., University of Latvia, 2012. 
socio-economic situation in Latvia worsened, ${ }^{17}$ and it did not strengthen the trust of the population in a state that cared for their prosperity and security. It also did not support national awareness and understanding that people and especially families form the basis of this growth ${ }^{18}$ and that they are entitled to rights, as well as responsibilities, to join forces in the construction of the new sustainable state. Tasks of national importance on several levels were to (1) develop civic consciousness ${ }^{19}$ (2) ideologically raise the self-identity and self-value of Latvian families' children and parent comparisons of the Baltic states and "successful" and "innovative" foreign countries, ${ }^{20}$ and (3) practically provide a Western-style social support system to secure the needs of the family and raise the quality of life. ${ }^{21}$

The transition to the market economy, in which individuals are responsible for providing one's own means of existence, frequently became extreme denial of joint responsibility, the collapse of industry, a rapid increase of unemployment and inflation, denationalisation, and devaluation of currency that affected savings and equities (bonds). The economic crisis caused rapid decline in the welfare of families with children. This situation also caused concerns regarding security, stability, and further development of the state. Families found it difficult to survive as social welfare constituted a little less than half of the state budget. ${ }^{22}$ An acute necessity to improve the social support system became more evident. Legislative changes demonstrated the necessity to audit the family issues within the legislative context and began to coordinate legislation with European laws and regulations concerning issues of family and children. ${ }^{23}$

We determined three evolutionary stages in social security (social security aid, labour protection, employment and health care) which ranged from chaotic and uncoordinated attempts to politically and strategically compliant but

17 A. Jākobsone (ed.), Bèrni un ǵimenes Latvijā 1994 [Children and families in Latvia 1994], Rīga, AS Preses nams, 1995.

${ }_{18}$ P. Eglite, 'Dzimstỉba un gimenes politika Latvijā 1990.-2009. gadä’ [Birth rate and family policy in Latvia 1990-2009], Latvijas Zinätñu Akadēmijas Vēstis [Latvian Academy of Science News], vol. 65 , no. 3/4, 2011, pp. 17-33.

${ }^{19}$ M. Kaprāns, 'Padomju laika sociālās reprezentācijas latviešu pēcpadomju biogrāfiskajā diskursāa [Social representations of Soviet era in post-Soviet Latvian biographical discourse], PhD diss., University of Latvia, 2012.

${ }^{20}$ Publications of the Yearbook from 1990 to 1996.

${ }^{21}$ L. Āboliṇa, 'Ģimene un tās atbalsta politikas attīstîba Latvijā (1990-2015)' [Family support policy and its development during 1990-2015], PhD diss., University of Latvia, 2016.

${ }^{22}$ Centrālā statistikas pārvalde [Central statistical bureau of Latvia], Latvija: Galvenie statistikas rādìtāji 1993-1994 [Latvia: Main statistical indicators 1993-1994], Riga, State Statistical Commission, 1994, p. 5.

${ }^{23}$ L. Āboliṇa, 'G̣imene un tās atbalsta politikas attīstība Latvijā (1990-2015)' [Family support policy and its development during 1990-2015], PhD diss., University of Latvia, 2016. 
realistically unenforceable measures due to lack of resources ${ }^{24}$ up to a targeted system of social welfare, support and services.

From 1990 to 1994, the social security and welfare system developed gradually, adopting laws and regulations that matched international human rights declarations Latvia had signed. ${ }^{25}$ Maternity allowances increased gradually, and support for disadvantaged families and large families was reconsidered. At the end of this period, implemented legislation was based on a universal approach towards all children, disregarding the financial situation of the family, its structure, or number of children. Minimum wage and amount of child support were regularly revisited and increased, but the high divorce rate created families with one bread-winner (in the 1990s, 29.9\% of all babies were born outside marriage, and civil marriage was not yet recognised $^{26}$ ), resulting in a situation below the crisis minimum. Child support or alimony were not yet provided. ${ }^{27}$

In the beginning of 1990s, additionally to state support, families received significant assistance from NGOs such as the Children's Foundation of Latvia in existence since 1989. ${ }^{28}$ MLO mentions the Foundation often. The Latvian branch of Save the Children - 'Glābiet bērnus' - provided not only practical support to Latvian families with children but also contributed greatly to raising awareness, with the help of mass media. ${ }^{29}$ The Latvian National UNICEF Committee could be felt in many areas related to family life, and they were also promoted in MLO. One UNICEF project was the breast-feeding project implemented together with the Latvian National Perinatal Care Centre (founded in 1995) that resulted in the translation and publishing of educational literature for parents. ${ }^{30}$

Study of the MLO narrative and analysis of academic literature in the early $1990 \mathrm{~s}^{31}$ indicates a correlation between problems of social pedagogy in society

${ }^{24}$ I. Pavlina, M. Brants, 'Valdības deklarētā demogrāfiskā politika un tās īstenojums Latvijā (1990-2002)' [Government declared state support and its implementation in Latvia (1990-2002)], in Apcerējumi par Latvijas iedzīvotājiem, Nr. 9: Ģimeņu veidošanās un valsts atbalsts gimenèm atjaunotajā Latvijas Republikā [Review of Latvian residents, no. 9: Family development and state support for families in restored Republic of Latvia], Riga, BO SIA LZA Ekonomikas institūts, 2002, pp. 31-47.

${ }^{25}$ Latvia is a member state of UN since 17 September 1991 and UNESCO since 14 October 1991.

${ }^{26}$ J. Vebers, 'Family Law in Latvia: From Establishment of the Independent State of Latvia in 1918 to Restoration of Independence in 1993', in A. Bainham (ed.), The International Survey of Family Law 1997, Netherlands, Martinus Nijhoff Publishers, 1999, pp. 207-227.

27 L. Āboliṇa, 'Ģimene un tās atbalsta politikas attīstība Latvijā (1990-2015)' [Family support policy and its development during 1990-2015], PhD diss., University of Latvia, 2016.

28 'Children's Foundation of Latvia.' Available: http://www.lbf.lv/lv (accessed 13 December 2018).

29 A. Jākobsone, Bèrni un gimenes Latvijā 1994 [Children and families in Latvia 1994], Rīga, AS Preses nams, 1995, p. 112.

${ }^{30} \mathrm{H}$. Kovacs et al., Kanādas vadošie medicīnas darbinieki. Bērna kopšanas mazā enciklopēdija [Leading Canadian health professionals. Encyclopedia of child health and care], Rìga, Jumava, 1995; 10 soḷi sekmīgai krūts barošanai [Ten steps towards successful breastfeeding], Latvijas Nacionālā UNICEF Komisija, 1994.

${ }^{31}$ A. Baldiņš, A. Raževa, Skolas un ǵimenes sadarbība [Cooperation between a family and school], Rīga, Pētergailis, 2002, p. 81. 
(large, poor, and disadvantaged families as well as cooperation between school and home) and the increasingly important role it played in the academic field and professional practice. ${ }^{32}$

From 1995 to 2002, the law 'On Social Support' ${ }^{33}$ was in force in Latvia. Demography was a priority during this period. To ensure an increase in population and improvement of the quality of life of the Latvian population in general (public health, education, culture, and public morality), the Cabinet of Ministers issued the regulation 'On Improvement of the Demographic Situation' directed towards development of laws and regulations and strategic long-term policy. Financial means were not provided for, but the Ministries of Welfare, Education and Science, Interior, Culture, and Environmental and Regional Development and municipalities were asked to develop and submit recommendations. The document was like a guideline: municipalities were recommended to provide free first aid kits to parents of newborns; differentiate utilities payments depending on the number of minor children (considering age and health conditions), anticipate funds in municipal budgets to subsidise public transport expenses for extra-curricular classes, compensate food and medical expenses for large and/or disadvantaged families, and subsidise public transport costs for low income and/or large families and organise summer leisure activities and employment for their children. These regulations supplemented legislation, ${ }^{34}$ and amendments affected family allowance calculation principles, adjusting them to a coefficient system.

At this time, MLO took on a consultative role, becoming a guide for parents about legislation that was ever-changing and only partially provided equality at a time when families lacked trust in the law and sometimes even questioned its legitimacy because of the deficiency of resources. ${ }^{35}$

Correlation is also seen between the changes in the market system: children's goods became more expensive and the amount of allowances increased. Again, MLO fulfilled a significant role as consultant by comparing prices of local and imported goods that sometimes were greeted with euphoria in the maintaining of household and caring for the children and their development both in terms of qualitative functionality and price and value ratio.

Upon reaching the lowest birth rate ever in $1998,{ }^{36}$ the Cabinet of Ministers 'On the National Programs for Implementation of Economical Policy' approved

${ }^{32}$ A. Raževa, A. Baldiṇš (eds.), Sociālpedagoğiskās inovācijas. Rakstu krājums [Socio-pedagogical innovations. Article collection], vol. 1, Rìga, Latvijas Universitāte, Pedagog̣ijas un psiholog̣ijas fakultāte, Sociālo un pedagogisko inovāciju fonds, SIA Elpa-2, 1999.

${ }^{33}$ Law 'On the Social Suppor' adopted 26 October 1995, in 2003 was replaced with the currently valid Law on the Social Support and Social Services.

${ }^{34}$ Legal Information Centre of the Ministry of Justice of the Republic of Latvia, Legislation of the Republic of Latvia. Family Rights, Madona, SIA Madonas poligrāfists, 1995, p. 199.

${ }^{35}$ A. Jākobsone (ed.), Bèrni un ǵimenes Latvijā 1994 [Children and families in Latvia 1994], Rīga, AS Preses nams, 1995.

${ }^{36}$ P. Zvidriņš̌ (ed.), Depopulācija un tās novēršanas iespējas [Depopulation and ways of averting it], Rìga, Zinātne, 2005. 
the national program 'Population of Latvia ${ }^{37}$ with the Minister of Welfare as its head. The aim of this program was to summarise information about the social security system and outline a short- and long-term development strategy. Optimisation of state support for families with children was anticipated by introducing new forms of support and by increasing the amount of existing benefits. At the end of 1999, the Ministry of Welfare developed the concept 'On the Support of Families with Children' with the aim to come up with an action plan that would promote formation of strong families and improvements in the demographic situation over a 10-20-year period. Although the government declared support for families, it did not provide real help due to lack of a common system of resource assurance. The new plan anticipated various activities for improvement of the status of families by encouraging families to assume basic responsibilities themselves, but the state would help in emergency situations only.

The conceptual catalyst of the practical support system and its achievable result was the turning point in public opinion on the preservation of values: strengthening of the role of family, its significance, and the need to restore its prestige. Overcoming family crises includes complex measures - activities promoting both mental and material factors in the formation of social and economical environment ${ }^{38}$ such as providing housing to families through a housing development loan program prioritising young families. Another activity anticipated payments in addition to the family allowance in August so children could better prepare for the start of school on 1 September. Paternity allowance was also considered, allowing parents to choose who would receive the allowance, as well as promoting more active involvement and responsibility of fathers in the rearing of their children. A ten-day paternity leave allowance was initiated and paid for starting from 2004. ${ }^{39}$

To promote expansion of families, social allowances for socially unprotected student families were initiated and school bus services were planned for children of families living in rural areas. An increase in social allowances was planned for low income families indirectly through increases in state subsidies for health and educational services used by families with children.

In total, this policy planning document reflected a progressive approach, but the state's attempts to improve the conditions of families could be measured only after several years. The measures did not satisfy the ambitions of political parties and the necessity for officials to prove the immediate efficacy of their decisions and actions. Therefore, policies usually included support for short-term

\footnotetext{
37 'Nacionālā programma 'Latvijas iedzìvotāii. 1998” [National program 'Population of Latvia. 1998'], POLSIS Politikas plānošanas dokumentu datubāze [Policy planning document database]. Available: http://polsis.mk.gov.lv/documents/342 (accessed 22 January 2019).

${ }^{38}$ Ministry of Welfare, 'Concept for the Support to Families with Children', Latvijas Vèstnesis [Latvia’s Herald], 10 February 2000. Availabe: https://www.vestnesis.lv/ta/id/954 (accessed 18 March 2020).

${ }^{39}$ L. Āboliņa, Ģimene un tās atbalsta politikas attīstība Latvijā (1990-2015) [Family and the development of its support policy in Latvia (1990-2015)], PhD diss., University of Latvia, 2016.
} 
activities. ${ }^{40}$ In solving social problems, the state focused more on tactical and not strategic initiatives. ${ }^{41}$ To a certain degree, this can be attributed to the specifics of a situation that demanded immediate solutions for escalated problems and growing negative public feelings that raised the level of frustration and requests for immediate changes in society. Specific solutions for some urgent problems partially neutralised the collision between people and political power.

Focusing on immediate short-term solutions, protection of the interests of children and families of future generations was left in the background. Nevertheless, development of the concept and its approval by the government outlined a new stage in the development of family state support policies since regaining independence.

From 2003 to 2008, family support was put on the policy agenda. Again, new progressive laws and regulations and policy planning documents directly or indirectly influenced the family; they institutionalised family support policies and introduced new functional family support tools. ${ }^{42}$

Until 2003, almost none of the system principles were implemented consistently or provided valuable input in the support of families and children rights. In 2004, discussions continued regarding the development of an optimal support system model. Discussions resulted with an action plan, 'State Family Policy from 2004 to 2013', under the Ministry of Children and Family Affairs. Each year, its task was to submit informative reports regarding implementation of the action plan to the Cabinet of Ministers. ${ }^{43}$ For the first time, this document merged activities related to children and family support policies, and many activities had multi or interdisciplinary approaches. However, a discussion of its results is outside the scope of this paper. As the fulfilment time of the Action Plan exceeds the scope of this study, we will not analyse results of this plan.

\section{Conceptual imperative and instrumental performance of child rearing activities}

When Latvia adopted the UN Convention on the Rights of the Child in 1991, the quality of life of children was set as a national priority, and parents and families were the priority target group. This affected not only legislation but also social processes. Messages were distributed through various communication channels that an emotionally healthy family environment and

${ }^{40}$ L. Āboliṇa, Ģimene un tās atbalsta politikas attīstība Latvijā (1990-2015) [Family and the development of its support policy in Latvia (1990-2015)], PhD diss., University of Latvia, 2016.

${ }^{41}$ A. Jākobsone, Bèrni un gímenes Latvijā 1994 [Children and families in Latvia 1994], Rìga, AS Preses nams, 1995.

${ }^{42}$ L. Āboliṇa, Giimene un tās atbalsta politikas attīstìba Latvijā (1990-2015) [Family and the development of its support policy in Latvia (1990-2015)], PhD diss., University of Latvia, 2016.

${ }_{43}$ Ministry of Children and Family Affairs, 'Informative Report on the Implementation of Action Plan Concept 'State Family Policy' from 2004 to 2013, results of 2005, 2006,' POLSIS Politikas plānošanas dokumentu datubāze [Policy Planning Document Database]. Available: http://polsis. mk.gov.lv/documents/1635 (accessed 22 January 2019). 
effective parental functions are the preconditions for the health of the new generation. ${ }^{44} \mathrm{~A}$ beneficial prerequisite for this concept was also studies of public values performed in the early 1990s that were frequently mentioned in MLO and Yearbook: they revealed that family was the first or second most important value for the nation. The hierarchy of values expressed in the results of the studies were a supportive precondition for revision of parent-child relations and relations between parents: the purpose was to strengthen parents as a significant, safe source of connection and support in personality development and the educational path of the child. ${ }^{45}$ This concept was emphasised even further when the UN proclaimed 1994 as the International Year of the Family.

Evaluation of the existing situation and calls for more focus on child rearing in families can be read in almost all sources devoted to family issues. ${ }^{46}$ Child rearing and learning was considered the source for the renaissance of the nation, initiating discussion about persperctive directions. The publishers of MLO restored the importance of child rearing tips, emphasising suitable and quality education as a necessity for broad development possibilities. Despite the swirl of pluralism and democracy in the social space, scholars and practitioners acknowledged that common reference points should be set for child rearing - traditions, ideals, approaches in defining goals, and desirable result and methods. In many ways, the already established consumer culture outside the borders of Latvia and protection of Latvian national ethical traditions were opposed to each other as a child rearing goal. Yearbook focused considerably more on the latter, but MLO's opinion of "correct" child rearing leaned towards support of consumerism culture. One might think that this was not a purposeful decision by the editors but more a natural result of content construction and specifics of topics. If child rearing issues in Yearbook were revealed in poetic and philosophical stories about ideal family relations and child rearing, emphasising the public moral imperative of Latvian folk songs, then MLO could be considered a practical parent's everyday guide with content having a more specific approach in daily child rearing.

New liberalisation and democracy slogans required sense, so stability and discipline in child rearing was discussed in almost every issue of MLO from various perspectives; for example, whether the discourse of rights and dialogue

${ }^{44}$ A. Jākobsone, Bèrni un gimenes Latvijā 1994 [Children and families in Latvia 1994], Rīga, AS Preses nams, 1995.

${ }^{45}$ Dž. Boulbijs, Drošais pamats. Vecāku un bèrnu savstarpējā pieķeršanās - cilvēka veselīgas attīstības priekšnoteikums [A secure base: Parent-child attachment and healthy human development], Rìga, Rasa ABC, 1998, p. 198.

${ }^{46}$ Publications of $M L O$ and Yearbook analysed in the study; see also A. Jākobsone, Bèrni un ǵimenes Latvijā 1994 [Children and families in Latvia 1994], Rìga, AS Preses nams, 1995; Dž. Boulbijs, Drošais pamats. Vecāku un bērnu savstarpējā piek̦eršanās - cilvēka veselīgas attīistības priekšnoteikums [A secure base: Parent-child attachment and healthy human development], Riga, Rasa ABC, 1998; European Economic and Social Committee Opinion 'The Role of Family Policies in the Context of Demographic Change to Promote the Exchange of Best Practices Between Member States', 2001. Available: http://lietussargs.lv/wpcontent/uploads/2011/05/MB_ ces804-2011_ac_lv.pdf (accessed 22 August 2017). 
can be combined with borders, standards, procedures and how that alters power relations in the family. It should also be noted that not all members of society, just like today, were enthusiasts of democracy; democracy had many opponents because it was an unfamiliar reality for Latvian society. ${ }^{47}$

The 1990s marked a crisis period in pedagogy. History and the era at the time was directed by academia and the representatives of power who believed pedagogical thought and ideas should be recreated into a new ${ }^{48}$ theory and practice - from authoritarianism to humanism - in which unique, free, independent and responsible personalities are the main purpose for child rearing and societal development. ${ }^{49}$

Attempts at democracy and autonomy of the personality can be seen in childrens' rights as determined in laws and regulations ${ }^{50}$ and also in the child rearing trend, expressed in MLO and pedagogical literature, to listen to the needs of children and respect them as a value and individual. ${ }^{51} \mathrm{~A}$ range of factors impacted the world view of the child - family, school, mass media, and other opinions expressed in the public space form a child's opinions about others as well as perceptions of him or herself. ${ }^{52}$ A significant responsibility of parents was to observe the principle of objectivity and regularity: $:^{53}$ avoiding sporadic, fragmented, and inconsistent behaviour and chaotic goals and promoting adequate but positive formation of the self-image of the child. Therefore, both MLO and pedagogical literature encouraged parents to help children to grow up brave, confident, and with a favourable attitude towards the environment. ${ }^{54}$

${ }^{47}$ A. Plakans, Concise History of the Baltic States, UK, Cambridge University Press, 2011.

${ }^{48}$ G. Korṇetovs, 'Pedagogiijas vēstures pētījumu metodologiijas pamatproblēmas' [Basic problems of pedagogy history research methodology], in A. Krūze (ed.), Laikmets un personība. Rakstu kräjums [Era and personality. Collection of articles], vol. 15, Rīga, RaKa, 2015, pp. 184-195.

49 A. Špona, 'Pedagogijas zinātnes daži metodologijas aspekti' [Methodological ascpects of pedagogical science], in RPIVA Zinātniskie raksti [RPIVA Collection of scientific articles], vol. 4, Rìga, SIA Petrovskis un Ko, 2004, pp. 10-18.

${ }^{50}$ A. Rektiņa, 'Apvienoto Nāciju konvencija par bērna tiesībām un Latvijas likumdošana' [UN Covention on Rights of the Child Law and Latvian Legislation], in A. Jākobsone, Bērni un gimenes Latvijā 1994 [Children and families in Latvia 1994], Rìga, AS Preses nams, 1995, pp. 83-90.

51 Dž. Boulbijs, Drošais pamats. Vecāku un bērnu savstarpējā piek̦eršanās - cilvēka veselīgas attīstības priekšnoteikums [A secure base: Parent-child attachment and healthy human development], Rīga, Rasa ABC, 1998; L. Grigule, I. Silova, Mācīsimies sadarbojoties [Learning through cooperating], Rīga, Sorosa fonds - Latvija, 1998; A. Špona, Audzināšanas teorija un prakse [Education: Theory and practice], Rìga, RaKa, 2001.

${ }^{52}$ D. Lieǵeniece, Bèrns - pasaulè, pasaule - bèrnā [A Child within the world, the world within a child], Rīga, Zvaigzne, 1992.

${ }^{53}$ A. Špona, 'Pedagoǵijas zinātnes daži metodologijas aspekti' [Methodological aspects of pedagogical science], in RPIVA Zinātniskie raksti [RPIVA Collection of scientific articles], vol. 4, Rìga, SIA Petrovskis un Ko, 2004, p. 15.

54 A. Vecgrāve, Kā uzveikt bailes [How to overcome fear], Rīga, Zvaigzne ABC, 1999. p. 24.; A. Vecgrāve, Kā uzveikt dusmas [How to overcome anger], Rīga, Zvaigzne ABC, 1999. p. 23; A. Bakisa, Mans bèrns nebaidās un paḷaujas uz sevi [My child is not afraid and relies on himself], Rìga, Alberts XII, 1999, p. 148. 
The shift of the child rearing paradigm from a totalitarian one to democracy was gradually implemented with the help of epistemological, theoretical, and practical knowledge that gave parents theoretically justified and applicable tips for child rearing. These tips, recommendations already embedded in the European culture and conceptual dimension, analysed the worldview and pluralism. Academic pedagogy was more inclined to disassociate itself from Russian culture imposed on the nation by Soviet power and to glorify the cultural heritage of Latvia ${ }^{55}$ as well as accept Western concepts without criticism. ${ }^{56}$

To rehabilitate and bring back national cultural virtues - Latvian public morals, endowments, importance of the family, home not as a living space but provider of the blessing of the life cycle of the child - Yearbook and occasionally MLO published the works of Latvian poets that were banned under Soviet dictatorship. It made people think about values, sacred and true things that should be emphasised in the spirit and heart of every Latvian. They also gave inspiration to parents in child rearing: it gave them power to be better caregivers. An invitation to humanise minds and care for the culture of the heart was also expressed in pedagogical literature. ${ }^{57}$ Both Yearbook and MLO had abundant material about Latvian national festivities and traditions, officially banned during the Soviet era, making implementation of these traditions a precondition for national identity and rehabilitation of the sense of belonging to Latvia. The power of national and family traditions was the time spent together, strengthening the sense of belonging in the atmosphere of the national awakening. It should be noted that both sources supplemented each other: Yearbook focused on philosophical thought and MLO was oriented towards practical topics and various situations.

With the revision of pedagogy, there was concern that the instability of the socio-political and economic situation, as well as changes in the educational processes, should not influence formation of the personality. The long awaited large "truth" hidden behind the Iron Curtain became problematic as the truth was not clear or undisputable. Unlike reading Soviet pedagogic literature, the reader had to select and form an opinion after the criteria he/she only knew (did not know). Both pedagogical literature and MLO regularly argued about the issues of value. They reconsidered the civic responsibility of individuals and society and rethought learning and child rearing theories and practice cherished in Latvia during the inter-war period and Soviet dictatorship in comparison to the politically free world of new Europe ${ }^{58}$ and the concepts that would provide optimal development of the personality in the family. A task was

\footnotetext{
${ }^{55}$ J. Anspaks, Pedagoǵijas idejas Latvijā [Pedagogical ideas in Latvia], Rīga, RaKa, 2003.

${ }^{56}$ Z. Rubene, 'Pedagogijas zinātne pēc Latvijas neatkarības atjaunošanas' [Pedagogical science after restoration of independence of the Republic of Latvia], in A. Krūze (ed.), Laikmets un personība. Rakstu kräjums [Era and personality. Collection of articles], vol. 15, Rīga, RaKa, 2015, pp. 105-134.

57 J. Anspaks, Pedagogijas idejas Latvijā [Pedagogical ideas in Latvia], Rīga, RaKa, 2003.

58 A. Plakans, Concise History of the Baltic States, Cambridge University Press, 2011, p. 490.
} 
brought forth in the entire field of education - preservation of national heritage and transfer of values to future generations, simultaneously bringing Latvia closer to European identity. ${ }^{59}$ MLO articles show ambivalent balancing between child rearing that should be conservative, trying to protect core values, but that should also be modern and even futuristic. Not only educational sciences, ${ }^{60}$ but also mass media indicated conceptual cancelling of and then gradual regaining of Latvian artefacts of values from oblivion cultivated by the Soviet power. The introductory part of the Yearbook of the beginning of 1990s and later MLO editors continued this direction until 2004 - to restore balance between the nationally general and globally international.

Complexity of the child rearing task in this period of transformation was determined by the hybrid identity of the state and individual, merging the national idealism discourse typical of modernism with democratic multiculturalism propagated by post-modernism. ${ }^{61}$ Post-socialism is characterised as open, versatile, and an inescapably indefinite phenomenon. On the one hand, this indefinite situation created almost dimensionless possibilities, but on the other hand, it was connected to the feeling of insecurity in society as the creation of a new social frame, sudden freedom, openness, and the uncertainty related to it was threatening. Society, including families, had acquired freedom from Soviet style socialism but it was placed before a choice to lose it gradually by adopting the thoughts and action models of the Western world uncritically and, again, politicising child rearing to a certain degree. A titanic task was to be done as future possibilities of post-socialism did not yet exist; ${ }^{62}$ therefore, they needed to be created and developed by applying one's own capacities, cleverly using what was available and attracting new resources.

${ }^{59}$ J. Anspaks, Pedagoǵijas idejas Latvijā [Pedagogical ideas in Latvia], Rīga, RaKa, 2003; V. Ūsiņšs, 'Latviešu tautas pedagogiijas atziņu nozīme bērna personības veidošanā gimenē' [Importance of Latvian folk pedagogical verities in development of a child's personality in a family], in S. Kramēna (ed.), Personības attīstība gimenē, skolā un augstskolā. Zinātnisku rakstu kräjums [Personality development in family, school and higher education institution. Collection of Scientific Articles], Rīga, SIA Mācỉbu apgāds NT, 1999, p. 90.

${ }^{60}$ A. Krūze, 'Audzināšanas mērkis un ideāli pedagoǵiskās domas attīstībā Latvijā' [The objective and models of education in development of pedagogical ideas in Latvia], in Vispārīga didaktika un audzināšana. Zinātnisku rakstu kräjums [General didactics and education. Collection of scientific articles], Rīga, SIA Izglìīibas soḷi, 2001, pp. 47-50.

${ }^{61}$ E. Kḷave, B. Zepa,'Modernisma un postmodernisma nacionālisma diskursi nacionālās identitātes skaidrojumä [Nationalism discourses of modernism and post-modernism in interpretation of national identity], in Identitātes. Kopienas. Diskursi [Identity. Community. Discourses], Rīga, Latvijas Universitāte, 2012, pp. 9-26.

${ }^{62}$ I. Silova, 'Globalizācija un postsociālisma pārmaiṇas izglīīibas jomā' [Globalisation and postSocialism changes in education], in T. Koḳe, A. Krūze, D. Markus (eds.), Apvienotais pasaules latviešu zinātnieku 3. kongress un letonikas 4. kongress. Zinātnisko rakstu kräjums CD formātā. Izglìtības izaugsmei: pagātne, tagadne un näkotne [Third World congress of Latvian scientists and fourth congress of Latvian studies. Scientific article collection in a CD format. For educational growth: Past, present and future], Rìga, 2011, pp. 1-9. 
The individuality of the child was increasingly highlighted and strengthened by attempts at decentralisation and differentiation..$^{63}$ Our study indicates a gradual increase in the necessity for psychological comfort in the family that promoted intellectual and emotional stability and development, mainly for children but also for parents. ${ }^{64}$ Authors of pedagogical literature tried to create structural frameworks and family typology by discovering typical traits for each family model and mutual relations between family members. ${ }^{65}$ MLO pages revealed those through experiences of celebrity and "ordinary" families that related to the organising principles of the family household and attitudes towards child rearing and formation of mutual relations.

Analysis of sources indicates that with the approach of the new millennium, the roles of families and functions changed. This highlighted the pedagogical cooperation model of a child, mother and father as equal actors. Asymmetry of the family reduced child rearing and support while family members participated in the domestic activities of the family. Decline of the stereotypical approach towards feminine and masculine is also seen in frequent messages about the merging of work and family life in MLO articles: the development of an inclusive environment would secure equivalent integration of both areas in household practice. ${ }^{66}$ The message about inclusion of fathers, gradually transfering child rearing responsibilities to both parents, ${ }^{67}$ encountered

${ }^{63}$ J. Anspaks, Pedagogijas idejas Latvijā [Pedagogical ideas in Latvia], Rīga, RaKa, 2003; A. Vecgrāve, Kā man saprast savu bèrnu [How to understand my own child], Rìga, Zvaigzne ABC, 1996; D. Liegeniece, Kopveseluma pieeja bērna audzināšanā (5-7 gadu vecumā) [Holistic approach in parenting (at the age of 5-7)], Rìga, RaKa, 1999; A. Špona, Audzināšanas teorija un prakse [Education: Theory and practice], Rìga, RaKa, 2001; A. Šteinberga, I. Tunne, Jauniešu pašizjūta un vèrtības [Self-awareness and values of the youth], Rìga, RaKa, 1999; Ā. Karpova, Personība un individuālais stils [Personality and individual style], Rīga, Latvijas Universitāte, 1994.

${ }^{64}$ I. Kraukle, 'Ģimenes kā pašregulējošas sistēmas varianti un to ietekme uz bērna personības veidošanos' [Types of a family as a self-regulatory system and its impact on development of a child personality], in S. Kramēna (ed.), Personības attīstība gimenē skolā un augstskolā. Zinätnisku rakstu kräjums [Development of personality in school and higher education institution. Collection of scientific articles], Rīga, SIA Mācību apgāds NT, 1999, p. 90.

${ }^{65}$ Ā. Karpova, I. Kraukle, I. Žogla (eds.), Ievads latviešu ǵimenes sociālpsiholoğisko, psihofiziologisko un pedagogisko īpatnību pētījumā: rakstu kräjums [Introduction into a research of sociopsychological and pedagogical peculiarities of a Latvian family: collection of articles], Riga, Latvijas Universitāte, 1992; V. Zelmenis, İss pedagoǵijas kurss [Short course in pedagogy], Rìga, Zvaigzne, 1991, p. 213; A. Tabūna, 'Equality Between Men and Women in the Family' in I. Koroleva (ed.), Invitation to Dialogue: Beyond Gender (In)equality, Rìga, Institute of Philosophy and Sociology, 1997, pp. 287-298; P. Stēnsgorda, Māte, bèrni un tềvs. 16 intervijas ar netradicionālām gimenèm [Mother, children and father. Sixteen interviews with non-traditional families], Rìga, Atēna, 2004.

${ }^{66} \mathrm{~N}$. Jansone-Ratinika, Tèva pedagoğiskā kompetence mūsdienu ġimenēe [Father’s pedagogical competence in family nowadays], PhD diss., University of Latvia, 2013.

${ }^{67}$ A. Žvinklienè, 'Gender Equality in the Baltic States: Democratisation of Patriarchy', in I. Novikova (ed.) Gender Matters in the Baltics, Riga, LU Dzimtes studiju centrs, 2008, pp. 73-90; I. Pavlina, 'Vecāku viedokḷi par iespējamiem pasākumiem tēvu dalības veicināšanai bērnu aprūpē' [Parents' ideas on possible measures to foster father participation in child care], in I. B. Zarina (ed.) Vỉrieša loma ǵimenē: Starptautiskās konferences materiāli [Man's Role in the Family: International Conference Materials], Rīga, LZA Ekonomikas institūts, 1999, pp. 176-181. 
contradiction through the traditional family model of one bread-winner as proposed by laws and regulations. In this model, one parent, mostly the father, provided the material resources for maintaining the family, and the primary role of the mother was child care, child rearing, and household chores. ${ }^{68}$

Both MLO and Yearbook indicate a collision of paradigms from intuitive to externally censored "correct - incorrect" towards freedom of expression "corresponding - non-corresponding" balanced with critical arguments. Mass media texts were intertwined with search for balance, and local and foreign experts of various sectors published recommendations for determining or democratising parental behavior. Parents manoeuvered between democracy and authoritarianism in child rearing. Analysis of the MLO Questions and Answers column shows that in the perception of authors and readers, MLO's narrative approach increasingly strengthened the principles of democracy in the mind of readers and encouraged liberalisation. It is also important to note that the cultivated Soviet ideology and political exclusion behind the Iron Curtain limited the individual through centralised obedience enforced by an iron fist but also provided some comfort, which was favourable soil for the development of freedom of choice and critical thinking. Parents were now required to think independently, make decisions, and alter their opinions. Expansion of the information space and expression of freedom alongside confusion also created harsh competition and forced readers to focus more on the quality of media content. ${ }^{69}$ Content creators and consumers developed a need for critical competences, ${ }^{70}$ something that was being increasingly researched and described in pedagogical literature.

It should be noted that MLO was the first print media devoted to child rearing, and members of society who had previously received only propaganda were eager readers. One of Latvia's most important achievements in its quest for democracy was freeing mass media from government officials and control of news. ${ }^{71}$ Content analysis shows that in the early 1990s, Yearbook texts were still didactic and simplistic, and MLO wrote cautiously, indicating that despite the collapse of official censorship, self-censorship - typical of the Soviet Union - still existed. To a certain extent, the articles replicated the pedagogical literature that flourished under Soviet power by discouraging revolution, yet

${ }^{68}$ P. Eglìte, 'Dzimstība un gimenes politika Latvijā 1990.-2009. gadā’ [Birth rate and family policy in Latvia 1990-2009], Latvijas Zinātņu Akadēmijas Vēstis [Latvian Academy of Science News], vol. 65 , no. 3/4, 2011, pp. 17-33.

${ }^{69}$ S. Veinberga, Mediju misija. Preses attīstības tendences Latvijā pēc valsts neatkarības atjaunošanas (1990-2010) [Media mission: Press development trends in Latvia after the restoration of independence (1990-2010)], Rīga, Zvaigzne ABC, 2010, p. 160.

${ }^{70}$ Z. Rubene, 'Kritiski domājošas personības veidošanās: ieskats pedagogiijas un psihologijas teorijās' [Development of a critically thinking personality: Insight into theories of pedagogy and psychology], in I. Žogla (ed.) Zinātniskie raksti pedagoóijāa [Scientific articles in pedagogy], vol. 641, Rìga, SIA Izglitīibas soli, 2001, pp. 243-252.

${ }^{71}$ S. Veinberga, Mediju misija. Preses attīstības tendences Latvijā pēc valsts neatkarības atjaunošanas (1990-2010) [Media mission: Press development trends in Latvia after the restoration of independence (1990-2010)], Rīga, Zvaigzne ABC, 2010. 
urging evaluation of the existing situation and search for a new path - since regaining independence, the public responsibility of mass media doubled. ${ }^{72}$ The change of media narrative and industry literature as well as acquiring pedagogical personnel and revising standard Soviet practice caused difficulties. Creators and developers of "new" educational concepts were also specialists of pedagogy under Soviet rule. They tried to change but were not able to accommodate rapidly.

As the purpose of media and pedagogical literature is to promote child rearing competences of parents, justification and consistency of the child rearing discourse should be especially analysed. Analysis shows that the content of MLO, especially in the 1990s, was still compiled chaotically and interpretation of pedagogical values did not show consistency with pedagogical literature. The purpose of consistency is not to develop a centralised, routine pedagogy but to help parents create systematic and targeted approaches in child rearing. Similarly, the public lacked a leitmotif and unified direction after regaining freedom, and the richness of MLO topics and initiatives created difficulties with orientation and systematisation, which did not foster conviction about the purpose of conceptualising pedagogical perceptions and understanding. Although MLO and Yearbook can generally be characterised as media sources with significant communication potential, ${ }^{73}$ scrutiny of the articles devoted to child rearing topics lacked the connection of theory with practice and academic validity.

During the 1990s and the start of the $21^{\text {st }}$ century, both Yearbook and later MLO tended to translate articles by foreign experts and consultants without providing information about the field the author represented or why the author was selected, which could have added deeper meaning and substance. Also, fragmented comments about topics sometimes created gaps of information that could develop into misunderstanding of cause and effect. This probably occurred because acquisition of expert opinions in journalism was done not by assessing competence but by ease of access. One cannot deny that editorial postediting could also change thematic highlights. Similar messages expressed by MLO and Yearbook could occur due to the fact that they were the only sources and had no competition from other publications. Issues of groundlessness and discrepancies were observed in MLO articles until 1996: deficiency of data acquired in Latvia was replaced with translations and descriptions of foreign studies that were not always applicable to Latvian families and their problems.

\footnotetext{
72 A. Dimants, Pašcenzūra pret paškontroli Latvijas presē. Mediju pētījuma atklājumi [Self-censorship against self-control in the Latvian press: Discoveries of a media study], Valmiera, Vidzemes augstskola, 2004, p. 115. Available: http://providus.lv/article_files/2102/original/pascenzura_ lv.pdf?1343208981 (accessed 17 November 2016).

${ }^{73}$ D. Medne, 'Pedagoǵisko vērtību interpretācija žurnālā 'Mans Mazais" [Interpretation of pedagogical values in magazine 'My Little One'], LU Raksti. Pedagoǵija un skolotāju izglìtība [University of Latvia articles. Pedagogy and teacher education], vol. 781, Rīga, LU Akadēmiskais apgāds, 2012, pp. 174-185.
} 
Disregarding the thread of individualisation through the entire child rearing discourse, media content still showed pedagogical categorisation traits of children, parents, and families, putting specific labels of "right" and "wrong", which sometimes was reflected as an almost irreversible pedagogical "diagnosis".

Both pedagogical literature and MLO narratives identified two contextual contrasts - pedagogical activity canons of biased parents and denials of idealised recommendations, justified by the creation of inferiority complexes in parents as an inescapable side effect. Pedagogical literature and MLO polarised the biological and social impact on the development of children's personalities and their life trajectories. Especially during the 1990s, several articles proposed diametrically opposite notions about the main personality aspects as defined by genes or socialisation and child rearing as the determining factors. This can be explained by the Soviet viewpoint that debunked heredity but which gained increased interest during the post-Soviet era.

Both educational theoreticians and MLO and Yearbook authors increasingly argued that changes in child rearing and educational targets in the family and society made one reconsider new personality upbringing and educational paths. In the early 1990s, the aim of education was to "Create favourable conditions for the growth of a free, creative and cultural person, who is directed towards the continuation of education; promote the creation of a member of a democratic society; and develop a person who is able to independently see and expertly solve life problems and work skilfully in their area on behalf of the state, family, and self." ${ }^{\prime 4}$ To a certain degree, this concept represents child rearing guidelines in the family as the aim of education should not be delegated only to schools but should be closely tied to family pedagogy.

Pedagogical messages reflected in various academic and popular science sources emphasised cooperation of families and schools in the development of humanity, individualisation, creative expression, democracy, and community principles. $^{75}$ In time, most MLO editions emphasised the role of family in the educational pursuits of the child. In addition, studies performed in 1990s identified a correlation between the family and educational achievements of the child, justifying the basic truth of pedagogy that family environment favourably impacts the grades of the child. ${ }^{76}$

${ }^{74}$ A. Jākobsone (ed.), Bèrni un gimenes Latvijā 1994 [Children and families in Latvia 1994], Rīga, AS Preses nams, 1995.

${ }^{75}$ A. Špona, Audzināšanas teorija un prakse [Education: Theory and practice], Rīga, RaKa, 2001; A. Karpova, I. Kraukle, I. Žogla (eds.), Ievads latviešu ǵimenes sociälpsiholoğisko, psihofizioloǵisko un pedagoǵisko ìpatnību pétījumā: rakstu kräjums [Introduction into a research of social psychological and pedagogical peculiarities of a Latvian family: Collection of articles], Riga, Latvijas Universitāte, 1992; V. Zelmenis, İss pedagoǵijas kurss [Short course in pedagogy], Rīga, Zvaigzne, 1991; Ā. Karpova, Gịmenes psihologija [Family psychology], Rìga, RaKa, 2000.

${ }^{76}$ L. Ezera, 'Jaunās paaudzes kvalitatīva attīstība dažāda tipa gimenēs' [Qualitative development of new generation if various types of families], in Latvijas sociāli demogräfiskās attīstības problèmas [Problems of Latvia's socio-demographic development], Rỉga, Latvijas Universitāte,1992, pp. 136-142. 
Content analysis show that MLO articles about the physical development and care of children appear more frequently than texts about their psychoemotional and cognitive development; to a certain degree, these could reduce or encumber parents' options to try to solve all child development needs with the content provided in the magazine.

Most frequent MLO topics featured were about the health of the child and the mother (including pregnancy), family labour, physiological and psychological aspects of the family, challenges of children's behaviour, leisure time of children, extracurricular education and involvement of parents, and changes in extracurricular education because of technology and the increasing popularity of the Internet during the latter half of the 1990s. Various technological effects were viewed in regards to parental child rearing experiences and pedagogy theories, as well as a sub-sector of research of mass media pedagogy, ${ }^{77}$ which reduced MLO's information-giving function but increased the role of information classification and analysis.

One of the dominant thematic groups that came up in content analysis of MLO was 'fashion' in a broader sense - pedagogy, toys, clothing, food, even children-parent and partner relations - that used specific canons to prove social belonging in certain social circles, including among progressive thinkers. Although MLO's thematic scope was usually socially practical, the viewpoint gradually expanded. MLO can be considered a valuable source as it was the only publication of its kind. As a significant agent in the discourse of child rearing and the family support system, it can be evaluated ambiguously as content lacked the target-oriented approach to help families choose a suitable child rearing approach to harmonise with everyday activities. On the one hand, it is a testament to the thematic freedom typical of the time, but on the other hand, contradictions in content and conflicting emphases indicate lack of conceptualisation of the discourse of child rearing. In total, sources analysed in the study provided a significant contribution for the development of pedagogical ideas in the family and public from 1990 to 2004 .

\section{Conclusion}

Post-Soviet discourse can be divided into two stages: the 'post-independence regaining' period until 1991, and the 'Europeanisation' discourse until Latvia joined the European Union in 2004. The Europeanisation discourse formalised orientation towards the unified global and European space that began even before joining the EU while Latvia began fulfilling the requirements for joining the "club". Ideological preconditions at this time reveal two ambivalent trends: society tried to partially restore the patriarchal order of the 1920s-1930s,

\footnotetext{
77 A. Krūmin̦a, 'Mediju pedagog̣ija Latvijā' [Media pedagogy in Latvia], in Z. Rubene, A. Krūmiña, I. Vanaga (eds.), Ievads mediju pedagogijā [Introduction into media pedagogy], Rìga, RaKa, 2008.
} 
but the course of democracy and emancipation required reformation of the traditional order.

Analysis of sources allowed us to conclude that in comparison to the framework of child rearing and care established and maintained under Soviet rule, responsibility was placed more in the hands of family after regaining independence, i.e. centrally organised and state funded options were reduced. Although many family and child support initiatives that left a positive impact on the rearing of children in the family and quality of children's lives in general were implemented, mistakes were made in the promotion of more successful and sustainable family policies. Results could have been more positive if they had achieved coordinated horizontal cooperation of all involved parties - ministries, government institutions, NGOs and public organisations, and professionals - by determining the unified, long-term investment direction, informing the public of changes in various sectors, and involving people in common tasks. Despite the great value attributed to the family, the state believed that not enough was done to sufficiently protect families.

Sources attest to joint globalisation trends. Gradual reduction of stereotypes and clichés - tough and non-critical, unjustified judgments and actions allowed the restoration and significance of parental functions in all aspects of life and delegated family rights that were conceptually and practically nonexistant under Soviet rule. Also, the improvement of the national support system allowed to strengthen the idea and understanding about the role of new families so that parents could raise their children and also successfully return to their professional life, not only to fulfil professional ambitions but also to provide sufficient support and quality of life for their family. 